\title{
Energy Strategy of the Russian Federation
}

\section{Natalia Victorovna Kuznetsova}

Doctor of Economics, professor, Department of World Economy, School of Economics and Management Far Eastern Federal University, Russia, 690950, Vladivostok, Suhanova St. 8

\section{Ekaterina Vasilievna Kuznetsova}

BBA, Specialist in International Economics, M.S. in National Security and Public Safety

\section{Doi:10.5901/mjss.2015.v6n5p160}

\section{Abstract}

The main purpose of this research is to analyze the qualitative change in vision on role of fuel and energy complex in the Russian Federation. Additionally, the quantitative aspirations were examined. Analyzed Energy Strategy-2020, Energy Strategy-2030, and Project Energy Strategy-2035 allowed us to draw an important conclusion: Russian professionals suggest not to consider fuel and energy complex, which plays a major role in the Russian economy, as a basis for development, but to view it as a support system for the development. The huge difference between the two is the suggested level of dependency of Russia on its fuel and energy complex. In addition, it was determined that Russian fuel and energy complex severely suffers from wear and tear of infrastructure and technological inferiority. Today, when energy industry has done so much to bring Russia back from her knees it is vital that the country goes out of the comfort zone it has created. Furthermore, it is unacceptable for businesses to continue exploration and production for private profits without more contribution to renewal of the fuel and energy complex and investing in technology. Those are the issues that will need to be addressed if the government wants to see a brand new Russia in future.

Keywords: Fuel and Energy Complex, Russia, Oil, Gas, Energy Strategy.

\section{Introduction}

\subsection{Scope of Russian Fuel and Energy Complex}

Production and consumption of energy resources is vital for the world, as we know it today. Russia is the fourth world producer of electricity, third producer and second world exporter of crude oil, fourth producer and first world exporter of refined petroleum products, second producer and first exporter of natural gas (Central Intelligence Agency, 2014; U.S. Energy Information Administration [EIA], 2014). Russia has largest proved reserves of natural gas, and is in the top ten countries by proved reserves of crude oil, Russia is the third largest generator of nuclear power and fourth largest by the installed capacity.

Fuel and Energy Complex (hereinafter FEC) of Russia is one of the most vital industries of the global energy market, and beyond doubt - most important sector of Russian economy. As of 2012, share of Russian FEC in both GDP and Russian producing industry was roughly $30 \%$, share in tax revenues to the country's budget $-51.7 \%$, share in export revenues $-65.9 \%$ (Zilberstein, 2014). Out of $29.7 \%$ share of FEC in GDP, crude oil industry secures $20.2 \%$ of GDP, natural gas industry $-6.6 \%$, followed by the electricity industry and coal industry. Share of FEC in export is mostly secured by the oil industry (roughly $50 \%$ of total export), followed by natural gas $-14.4 \%$, followed by electricity and coal industry.

FEC of Russia includes crude oil-extracting industry, petroleum refining industry, natural gas, coal, and nuclear power industry, electricity industry, fossil fuel industry, heating industry, pipelines, grids, and other energy transmission infrastructure.

During several last decades Russian FEC has been mostly providing country's demand, which allowed preserving energy security of Russia and its competitiveness on the global market. FEC is crucial for ensuing economic stability of the Russian Federation. Due to a variety of hindrances on the way of development of Russian economy, occasional instability, and general unpredictability, role of FEC has grown. State of FEC in Russia defines internal stability and geopolitical potential of Russia in the region. 


\subsection{Two Stages of Development of Russian FEC}

Evolution of Russian FEC can be divided into two stages: first - between 1850 and 1950, second - since 1950 till present day. The main difference between the two stages is the prioritized resource.

During the first stage, which lasted till 1950, coal was the main energy resource in Russia. Growth rates of both coal and oil industry has depended on governmental policy. Before 1950, Russian governing body managed oil industry primarily towards satisfaction of internal demand. Crude oil was almost never exported.

At the present stage electrical energy, natural gas, and crude oil have started to dominate Russian FEC. It was a big step for USSR-Russia towards progressive transition of energy industry. It was during this stage when Russia became one of the world leaders in supplying of energy resources. Internal demand has also been completely satisfied by the country's own industry. One of the main problems of the present stage is that extraction of gas and oil resources has had more attention versus efficiency and process engineering.

\section{Energy Strategy of Russian Federation}

\subsection{Transformation of Vision from First Strategy to the Last}

In the years 2002 and 2003 the country kept recovering from the crisis of 1990th in nearly all the areas of the country's existence. The major transformation of politics, socio-economic system, and changes of geographical borders kept taking place. The government introduced new mineral extraction tax and new ways of calculating natural resources export dues, which however was criticized for its unfairness; Russia started using Blue Stream supplying natural gas to Turkey, president Putin signed five enactments into law, that became a legal basis for the electrical energy industry reformation ("History of new Russia: 2002," n.d.; "History of new Russia: 2003," n.d.).

As the role of FEC in Russian economy has always been vital, Russian government produced one of the first most important strategic documents of new Russia.

August 28, 2003, first Energy Strategy of Russia, for the period till 2020 was approved (Ministry of Energy of Russian Federation [MoE], 2003; "Projects - Energy Strategy of Russia - 2020," n.d.).

The goal of the Energy Strategy 2020 (hereinafter ES-2020) was - the most effective use of natural resources and potential of energy sector for the purposes of sustainable economic growth, improvement of quality of life, and promotion of the country's global interests (MoE, 2003, p.4). As stated in ES-2020: "Russia has meaningful resources of energy and powerful fuel-energy complex, which is a basis for economy development, tool for conducting internal and external politics. Role of the country on the world's energy markets largely determines its geopolitical influence. Energy sector provides vitality of all areas of national economy, ... in many ways determines formation of main financial and economic indicators of the country" (MoE, 2003, p.4). As suggested in the strategy, Russian energy industry is crucial for further growth and improvement of quality of life. ES-2020 set the main goal: define ways to achieve a brand new state of energy complex, and growth of competition capacity of its products and services on a global market (MoE, 2003, p.5).

November 13, 2009, second Energy Strategy was approved, for the period till 2030 (MoE, 2009; "Projects Energy Strategy of Russia - 2030," n.d.).

ES-2030 merely kept the old vision: the goal was to maximize utilization and increase of effectiveness of energy complex in order to sustain economic growth, improve the quality of life and strengthen the country's global position (MoE, 2009, p.1). ES-2030 also shaped new priorities of development of energy industry in frames of transition of Russian economy to an innovational development, - the vision that was introduced as part of a Concept of a Long-Term Socio-Economic Development of Russia till 2020 approved a year before ES-2030 was approved (MoE, 2009, p.1). The Concept determined the strategic goal of Russia as formation of qualitatively brand new Russia that complies with a profile of a world leader in the twenty first century (Government of Russian Federation, 2008). The need for innovations together with growing ambitions of the country was determined by many factors: comparative strengthening of socioeconomic quality of Russian national economy, world financial crisis, growing ambivalence towards Russia on the global political arena, exploration of Arctic, reformation of armed forces, in addition - Gas Exporting Countries Forum was legally established in Moscow and first summit of BRIC was conducted in Yekaterinburg ("History of new Russia: 2008," n.d.; "History of new Russia: 2009," n.d.).

Change of accents in the vision on the role of energy industry in Russia from ES-2020 to ES-2030 was in many ways an expected transition for the once to be one of the greatest powers of the world that fell into a destructive revolutionary reorganization. The country got out of the complete chaos of $1990^{\text {th }}$, gained strength and by the end of first decade of the twenty first century appeared to be a completely different power. 
February 17, 2014, Analytical Center for the Government of the Russian Federation together with Ministry of Energy of Russian Federation (hereinafter MoE) and Russian Union of Industrialists and Entrepreneurs conducted first public forum discussing Energy Strategy 2035 (hereinafter ES-2035); the project was almost unanimously acclaimed ("Projects - Energy Strategy of Russia - 2035," n.d.; "Project energy strategy of Russia till 2035 will be discussed February 17, 2014," 2014).

As of March 2015, Minister of Energy announced that it is planned that corrected ES-2035 will be considered by the government summer 2015 ("Medvedev will conduct a conference to discuss energy strategy of Russia till 2035," 2015). As of February 2015, 263 page preliminary Project ES-3035 can be found at MoE website (MoE, 2014). Though ES-2030 had a small points made about necessity to giving up FEC as a main industry in Russia, it is Project ES-2035 that brings revolution.

The revolutionary change in vision assumed by Project ES-2035 versus old strategies is in the role of FEC in development of the Russian Federation. Project ES-2035 points out: "ES-2030's main idea is that [Fuel and Energy Complex] must become an engine for development of the county's economy. ... The current strategy's main idea is a transition from resource-extractive to resource-innovational development of FEC. At the same time new role of FEC in the country's economy will be illustrated through the transition from 'engine for development' to 'stimulating infrastructure,' that provides conditions for development of the Russian economy, including its diversification, growth of technological level, minimization of infrastructure limits" (MoE, 2014, p.6).

\subsection{Expectations and Results: from ES-2020 to ES 2035}

\subsubsection{ES-2020}

ES-2020 assumed several optimistic expectations: GDP growth times 3.3 by 2020 compared to 2000 rate, growth of investments in capital assets times 7, high world prices for Urals crude oil (up to 30 usd/barrel in 2020) and natural gas (138 usd/1000 cubic meter in 2020), GDP per person 179.2 thousand rubbles/person (calculated at prices of 2000), and share of FEC in Russian industry would be $19.8 \%$ versus $29.5 \%$ in 2000 . Optimistic scenario was based on successful implementation of economic reforms, liberalization of market, effectiveness of energy industry, favorable trade relationships with other countries and successful integration with World Trade Organization that would allow favorable solutions of transit and transportation problems for energy industry. The importance of formation of a unified energy transit infrastructure in bordering regions of Europe and Asia was pointed out in the ES-2020. The scenario was characterized by the high level of energy effectiveness and fast downsizing of energy intensity. Critical (worst case) scenario of ES-2020 presumed complete and fast-paced realization of economic reforms, in conditions of unfavorable external circumstances, oriented towards fast diversification of economy and lowering social burden for the budget. In other words, unfavorable combination of internal and external conditions (first of all - low oil prices and demand for resources) would dictate the necessity to perform bulk of reforms that would "lead to negative economic growth rates and social tension in first years. However it would allow to free economy from burdens of reforms in future..."(MoE, 2003, pp.10-16).

ES-2020 expected to achieve following basic results (MoE, 2003, pp.115-118):

- Decreasing energy intensity to GDP and growth of energy effectiveness (energy intensity would decrease from $22 \%$ in 2000 to $13-15 \%$ in 2020);

- Internal demand for primary fuel and energy resources would be completely satisfied, in the same time fuel and energy expenditures per person would moderately grow against faster growing personal income;

- Yearly FEC revenues would grow by 1.5 by 2010 , with collected tax increased by $1 / 3$;

- Export of energy resources would grow $45-64 \%$ by 2020 , which would satisfy sustainability of country's balance of payments, and strengthen its economic state and influence.

\subsubsection{ES-2030}

ES-2030 confirmed that most of the tasks posed by ES-2020 have been brought to action. The mechanisms of energy policy were implemented. Mechanisms such as electrical power reform, liberalization of electrical power market, reform of nuclear power, creation of favorable tax environment in energy industry, realization of infrastructure projects that enforce development of country's energy industry, etc. (MoE, 2009, pp. 2-3). However the final qualitative results of the first stage of strategy's implementation were not achieved. Specifically those results include creation of a basis for a sustainable 
development of energy industry such as: formation of legal statutes, creation of competitive market with fair principles of trade, finalizing energy efficiency reorganization for relating industries, and most importantly "transformation from a leading role of energy fuel and energy complex in the national economy to its natural function as an effective and stable supplier of fuel energy resources for the needs of the economy and population" (MoE, 2009, p. 3). Major changes in basic economic indicators had happened in 2008: (MoE, 2009, p.3):

- Urals crude oil price grew from 27usd/barrel in 2000 to 94usd/barrel in 2008, (which exceed predictions by 4);

- Export of fuel and energy resources grew 1.6 times from 2000 to 2008, exceeding the expectations of ES2020 by $9.6 \%$;

- GDP grew 65\% from 2000 to 2008 , which was an $11 \%$ deviation from ES-2020

- Actual surplus of extraction and production of fuel and energy resources was $26 \%$ compared to $2000-2.6$ deviation from projections

- Internal demand for fuel and energy resource grew $10 \%$ compared to $2000-5 \%$ deviation from projections (as explained by the global economic crisis).

ES-2030 above all pointed out a goal of creating innovational and effective energy industry that among everything else secures innovational development of the county, determines necessity for raising effectiveness of the industry, favorable institutional environment, national economy's integration into world energy trade (especially further integration in European and Asian space), and modernization and renewal of energy industry infrastructure (MoE, 2009, p. 5).

By the time ES-2020 was due for an update, the global crisis changed expectations of original strategy. In 20082009 developers of ES-2030 admitted that specific path for innovational development and accomplishment of main goals might change. The hypothesis about relations between national economy and energy industry of the updated strategy were in essence determined by the decrease of dependence of national economy on energy industry which will be evaluated as decreases in following indicators by 2030 in comparison to 2005 (MoE, 2009, pp. 5-7): share of fuel and energy complex in GDP and its share in export - not less than by 1.7; share of fuel and energy resources in GDP - more that by 3 times; share of capital investments in FEC in percentages to GDP - not less than by 1.4, and its share in the total capital investments - more than by 2; energy intensity in GDP - more than by 2, electricity intensity in GDP - not less than by 1.6. In the same time it was pointed out that in frames of ES-2030 the role of fuel and energy complex is vital for important strategic tasks of the country's development. Building of new energy infrastructure would be also vital for development of Siberia and Far East regions. ES-2030 adds to the list of the expected results pointing out importance of transition to a sustainable innovational way of development (MoE, 2009, pp. 86-87):

- Necessary development of energy industry infrastructure in order to increase efficiency of the industry;

- Russia should become a regional leader in energy security of Eurasia by effectively influencing price policy on regional market making it predictable and stable, complete integration with Eurasian energy transit system, securing export-import relationship by an active dialogue;

- Russian energy industry should be completely renewed - it should be modern, high technological, effective, and sustainable, and should not only rely on resources, but also on human capital and innovational potential;

- Provision of energy security for Russian Federation and all its regions;

- Exploration of new regions.

In the light of necessity for larger corrections in energy strategy than expected, ES-2030 proposed 3 stages, different from what was presumed in ES-2020 (MoE, 2009, pp. 11-13):

1. First stage - recovery from crisis and formation of basics for new economy, exploration of opportunities that exist during crisis for qualitative renewal and modernization of the industry. This stage is characterized by renewal of infrastructure and fixed production assets, including finishing earlier started most important projects, exploration of territories and regions in terms of further development of infrastructure, completion of basic market and legal tools and system of governmental regulation in energy industry. The times frames for ending of the second stage would be conditioned by the length and strength of the crisis. Approximately - by 20132014;

2. Second stage - transition to innovational development and formation of infrastructure of new economy. The main focus of the stage would be raising energy efficiency in FEC as the result of the first stage modernization of fixed production/capital assets and finishing legal frameworks and institutional reformation, realization of projects in East Siberia, Far East, Arctic, and Yamal. Beginning of innovational renewal of FEC, it was expected that FEC would give in its positions as a leader account of national budget in favor of innovational sources of growth (manufacturing and high-tech knowledge based services);

3. Third stage - stage of innovational economy development. The stage would be characterized by the new 
technology and transition to energy of future. Third stage was presumed to be completed by 2030 .

\subsubsection{Project ES-2035}

Project ES-2035 is oriented towards energy security, energy effectiveness, budgetary effectiveness of energy industry, ecological security (MoE, 2014, pp. 6-7). Project ES-2035 also points out that previous strategy deviated from expectations due to new challenges and that one of the main disadvantages of Russia is its technological inferiority (MoE, 2014, pp. 4-9). The analysis of current progress (as of 2012) was presented in the Project ES-2035 (MoE, 2014, pp. 1119):

- Energy security has been mostly preserved, excluding short-term interruptions of separate regions. The share of resources that are difficult for extraction grows. Wear and tear of capital assets of FEC is extremely high (up to 60\%) in addition to the fact that capital assets renewal is slow, including construction works. Established expected rates of investments varied from industry to industry: investments in oil and coal industries outstood the expectation, gas industry and electricity - almost matched the expectation, heating industry - falling far behind the expectation (by 2.5). Generally Russian FEC still falls far behind the world scientific-technological level in the energy industry. One of the most serious dangers of Russian fuel and energy balance is its high dependence on natural gas and low quality of energy products and services. Though 2012 was marked by lower share of natural gas in extraction of primary fuel and energy resources - $40,3 \%$ (compared to $42,3 \%$ in 2008), it is still a high number.

- Despite of the crisis energy intensity of Russian economy decreased from 2008 to 2012 by $2.2 \%$. This result was achieved with the help of slow reorganization of GDP and general industry recovery growth. The positive results of new technology partially overlap by the high wear and tear of FEC. It is pointed out that achievement of goals set by first stage of ES-2030 is unlikely because the potential of structural changes in lowering the industry's intensity is mostly exhausted. As for the possibility of improvement of the situation by applying technological saving - the possibility is not an option because Russian technological level is far behind the normal level. The level of energy intensity of production of the most important Russian products is 1.2-2 times higher than world average, and 1.5-4 times higher than best world results. Low energy efficiency contributes to the low competitive advantage of Russian manufacturing.

- Investments of Russian FEC into Russian economy continued to grow - it reached $43,4 \%$ of investments of medium and large business. This number grew 13,1\% from the level of 2008. Considering that ES-2030 set the expectation of $18 \%$ by the end of first stage - it is a good result. Input of FEC in the federal budget surplus grew up to $50 \%$ - the expected number set by previous strategy was $30 \%$ by 2015 . Thus we can conclude that dependency of Russian economy on FEC grew considerably in 2012 compared to 2008. Processing industry, just as other sectors of Russian economy, still suffers from poor price and tax policy, low energy efficiency and low quality of resources. Project ES-2035 points out the necessity of investments in science and technology in order to develop FEC.

- Ecological security of FEC is still risky and does not match the expected levels set by ES-2030 because of the technological retardation of FEC.

- FEC has been mostly developing in the expectation frames set by ES-2030, however, there have been certain deviations in basic economic indicators of the country and changes in external economic and global conditions. Despite the fact that GDP only grew 3.9\% (in 2012 compared to 2008) and has almost reached the lower border of the ES-2030 prognosis corridor, production and extraction of fuel and energy resources grew $2.8 \%$ to 2008 , which was higher than expected. Internal consumption grew much slower than expected. Due to efforts of oil companies and stimulating measures of the government extraction of oil grew 6,3\% in 2012 compared to 2012, which is $4.8 \%$ higher than expected. Coal extraction has already outgrown the highest expected result set by the end of the first stage. However in the opposite to oil consumption, coal consumption is not optimistic due to intensity of world competition and growth of share and prices of gas. Extraction of natural gas has decreased 1,4\% in 2012 compared to 2008; this result is falling behind the prognosis. However the dynamics might be changed by the increase of demand in the case of favorable market conditions. Project ES-2035 optimistically presumed that the goals set by first stage of ES-2030 realization will be achieved. Electrical energy production and consumption has grown in accordance with the prognosis levels. Export of fuel and energy resources grew 2,9\%. Export of oil decreased 1,3\%, which despite the shortage is not far from the prognosis level. In 2012 we saw the trend of decreasing of export of crude oil and 
increase of export of petroleum products (18\% in 2012 compared to 2008). Export of natural gas decreased by $9,4 \%$. Natural gas has been declared on of the main risks of the country's export development. As of 2012 the risks were defined as mainly coming from shortage of Russian natural gas on the European market due to slower pace of European economy, higher competitiveness of liquefied natural gas (mostly from middle east), and substitution of gas by coal and renewable sources of energy. Principal factor of decreasing of export of natural gas to neighboring countries was decrease of supply to Ukraine. Export of coal has grown considerably. If the quantitative indicators mostly matched the expected levels, the qualitative indicators of improvement of FEC have been largely falling behind such countries as Norway or United States.

- There has been considerable policy and strategy changes in tax system and other areas of fuel and energy, including changes for private households. The legal statue that would regulate FEC has not yet been developed. The profit tax in the area of FEC is still an issue.

- International cooperation has been developing. Russian oil and gas companies have been actively involved in projects with foreign partners. There was a considerable advancement in the diversification of export and foreign cooperation.

\section{Challenges and Reality of Russian FEC}

\subsection{Realization of Energy Strategies up to 2015}

Energy Strategy of Russian Federation is somewhat a controversial document, first of all due to its suggestive nature, and second, because of the first circumstance it is becoming more difficult each year to create realistic prognosis because the players on the energy market do not behave in accordance with the given strategy.

In the past twenty years technological inferiority of Russia has been one of the major obstacles for development. As mentioned earlier, wear and tear of FEC capital assets is almost $60 \%$ by new estimations, with more than $83 \%$ of buildings, $70 \%$ of boilers, 70\% of power grid equipment, and 66\% of heating networks were built before 1990 (MoE, 2014, pp. 11-12). It is also estimated that wear and tear of capital assets in electricity energy industry $-40 \%$, gas industry 60\%, oil industry - 80\% (Pluzhnik, Saprikina, 2013, pp. 41-50).

Wear and tear of capital assets lead to more accidents. Russian Federal Service for the Ecological, Technological and Nuclear Supervision supervises exploitation of 65 thousand dangerous facilities for gas distribution and production, including 421 thermal plants, more than 60 thousand gas heating and producing boilers, more than 21 thousand liquefied petroleum gas facilities (Kutiyn, n.d.). According to some estimates wear and tear of some Russian hydroelectric power plants reaches $70 \%$, which is absolutely unacceptable. In 2010, roughly $70 \%$ of main-truck oil pipeline were more than 20 years old, and half of them is being exploited for more than 30 years (Pluzhnik, Saprikina, 2013, pp. 41-50). Despite the statistics, rates of renewal of capital assets in the past 10 years has been roughly $2 \%$, excluding oil extraction - $4 \%$. In 2012 , number of accidents in electricity industry decreased $5.3 \%$ compared to 2011 , oil industry - decrease $10 \%$, and coal industry - increased $3.1 \%$.

Roughly only $62 \%$ of investments that have been planned for the first stage of ES-2030 have been brought to the industry (MoE, 2014, pp. 11-12). First stage was presumed to be completed by 2013-2014, and was largely focused on renewal of infrastructure. According to new prospects of Project ES-2035, Alexander Novak, Minister of Energy, reported that Russia will require approximately 2.5 trillion of dollars by 2035 for development of fuel and energy complex ("Novak: energy strategy project will require $\$ 2.5$ trillion of investments," 2015). However Prime Minister Dmitrii Medvedev suggested that share of imported equipment and materials in fuel and energy complex should not exceed 10\% ("Medvedev announced the necessity to decrease share of import in FEC to 10\% by 2035," 2015). Russian own technology and equipment is being pointed out in terms of technological renewal of the industry. Dmitrii Medvedev noted that the strategy that is based on increase of energy resources from well-explored fields and export of energy resources does not work anymore.

Fuel and energy complex industry is still largely focused in Western Siberia and Urals-Volga Basin, however more efforts has been applied to create infrastructure in in East Siberia, Russian Far East, Russian Arctic, and other potential exploration fields.

Roughly $77 \%$ of proved oil reserves are located in working field, however $60 \%$ are exhausted (Ministry of Economic Development of Russian Federation [MoED], 2013, p. 187). Fields that require more financial investments, such as fields located in harsh climate or far from infrastructure, are high in number. About $67 \%$ of resources are difficult for extraction. If the oil production is kept on a current level, explored oil resources will be enough for more than 30 years.

Roughly $90 \%$ of Russian resources of gas are in Ural Federal Region, but the share of resources that require more 
financial investments, such as fields located in harsh climate or far from infrastructure, are also high in number (MoED, 2013, p. 190).

In terms of export Russia still largely relies on Europe. Approximately $79 \%$ of Russia's crude oil export (out of approximately 5 million bbl/d in 2012) and 81\% of natural gas export goes to Europe (EIA, 2014). Russia supplies around $30 \%$ of Europe's gas demand each year (Hodges, 2014). Asia is the second largest receiver of Russian energy export. Asia receives $18 \%$ of crude oil export and all of the Russian liquefied natural gas (LNG) through Sakhalin Energy's LNG plant, located in the Far East of Russian Federation (EIA, 2014). Turkey receives 19\% of Russian natural gas export. Russia makes an emphasis on growing demand on energy resources in developing countries, especially China and India, which might lead to growth of global demand by $45 \%$ by 2035 (MoE, 2013, p. 8). Russia expects that Asian demand for Russian energy will grow and take a bigger share in it export; Russia also expects that share of FEC in GDP will decrease to $15 \%$ by 2035 , however so far the number has not came even near to the level desired for 2015.

\subsection{Future challenges}

Russian energy security has two sides: Russia is both one of the largest energy consumers and producers. In addition Russia is important transit country and export partner. However, in the world of growing competitiveness, and as Russia is still extremely dependent on its FEC in terms of budget revenues, the challenges of Russian FEC must be addressed with top priority.

General Director of Institute of Energy Strategy, V.V. Bushuev, PhD, defined following challenges of Russian FEC in terms of Project Energy Strategy 2035 (Bushuev, 2014):

- Aging of infrastructure and capital assets;

- Technological inferiority of Russia FEC compared the level of foreign countries;

- Unproportional investments in industries and regions;

- Final consumer (domestic) price raise;

- Necessity of all-round development of technological energy efficiency and more efficient processing of primary fuel and energy resources;

- Stagnation or slow growth rates on traditional export markets for Russian carbohydrates, primarily in European Union;

- Harshening of competition on key energy markets;

- Transition from resource globalization to regional energy self-sufficiency;

- Instability of world energy markets and volatility of world prices on energy resources. In order to overcome the challenges the following is planned (Bushuev, 2014):

- Overall modernization and development of FEC and FEC infrastructure;

- Development of domestic market and increase of accessibility and quality of energy;

- Increase of energy efficiency on all stages of energy production and consumption, in addition to a product diversification;

- Increase of flexibility and diversification of export, in addition to preservation of Russian export share in the world market;

- Implementation of strategy of sustainable growth and governmental regulation of FEC development;

- Development of FEC in East Siberia and Far East, exploration of energy resource potential in the continental shelf of Arctic Ocean and north of Russia;

- In addition to preservation of positions on traditional markets of EU and Asian Pacific Region, creation of unified energy space in frames of Eurasian Economic Union;

- Integration of Russian companies within the global fuel and energy business.

In the light of new political circumstances of 2014-2015, it is very possible that Project ES-2035 will be corrected (most likely - time frames and worst and best case scenarios), however the main challenges and goals will most likely not change. It will, however, be more difficult to achieve the goals.

\section{Conclusion}

\subsection{Discussion}

Fuel and energy complex plays a dual role for Russia. From the one hand it is a treasure of Russian land that gives it an 
unprecedented advantages: it supports the economy (profits from export, creation of business and infrastructure, workplaces), it gives the country extensive geopolitical power, Russian people and businesses do not depend on outside agents in terms of energy supply. On the other hand FEC for Russia is a curse: Russia has built its economy around FEC so that the country vitally depends on it, Russia automatically has potential millions of dollars to be spent on aging infrastructure. Since 1950 oil and natural gas have established themselves as main resources, and the country started to develop larger system of infrastructure than it had previously. After Soviet Union collapsed much of the fuel and energy industry temporarily went out of order. It took Russia about ten years to figure out how to function in new established environment with all the given factors. In the beginning of the 21-century situation became clearer, but the need for short and long-term strategy for FEC became obvious.

One of the main conclusions of this overview is that strategic goals of the government in terms of FEC have changed tremendously from 2003 to 2014. First Energy Strategy of Russia Federation, approved in 2003, presumed that fuel and energy sector is a basis of economic development and a geopolitical tool, in all aspects FEC of Russia - is vital. Second Energy Strategy, approved in 2009 had a more ambitious goal - qualitatively brand new Russia that complies with a profile of a world leader of the twenty first century. The second strategy kept the same old vision of role of FEC in Russia's development, though voiced eventual necessity for transition. Project of the third Energy Strategy to be approved in 2015 (by preliminary estimations) has a revolutionary new vision: FEC of Russia must serve as a strong, technologically advanced stimulating infrastructure rather than main engine of development.

Setting up strategic goals in 2003 and 2009, all of the aims were brought to live only to some degree: some of the reforms have been brought to life; market has been liberalized to some extent; export has grown, but the relationship with most important economic partners has been fluctuating to extreme levels - Russia has not became a regional reliable leader; exploration and production grew, however it was mostly focused on working fields, progress in new regions has been rather slow; not much has been done in terms of renewal and technological modernization of infrastructure, however the share of resources that are difficult for extraction grows.

Thus, it is premature to say that the first stage of development set by ES-2030 hoped to be achieved by 2013-2014 was completed. Russia is still in the process (rather slow one) of renewal of its infrastructure and fixed capital assets, exploration of territories and regions in terms of further development of infrastructure, and completion of basic market and legal tools and system of governmental regulation in energy industry. At this point it is too early to talk about energy efficiency.

Russia severely suffers from technical inferiority and until it is fixed it is very likely that new challenges will keep coming up, especially considering that Russian internal and foreign policy is not focused on aiding the fuel and energy complex. One of the main problems is wear and tear of capital assets, which is even now is in unacceptable levels, but it is alarmingly dangerous in the long term - it will prevent one of the main goals which is preserving energy security.

On a positive note, it is important to add that critical scenario suggested in 2003 has been so far avoided and so far no fast paced reformation of economy that would lower social burden for the budget was needed. Current situation with Russian artificially motivated internal crisis however makes that possibility still realistic. Energy security has been mostly preserved and internal consumption has been satisfied.

Renewed vision on FEC in Russia assumes complete renewal of FEC foundation, building and rebuilding infrastructure with innovative technology, attraction of investments to all necessary fields, satisfaction of final domestic consumer, exploration of new global partnerships. For that Russian businesses and government must be considerate in their decision-making process.

\subsection{Scope for Further Research}

Energy Strategy of Russian Federation is a very important document, which not only allows looking into rare statistics, but also, most importantly, defines aspirations for FEC of Russia developed by professionals who understand the importance of FEC for Russian economy, and desire its development. Once final Energy Strategy - 2035 is approved, it would be necessary to see how much has been changed compared to the current project in connection with harsh political crisis that prevents a lot of investments and partnership at least for the short-term. It would be useful to know how the main predictions or means of obtaining goals have been changed because it might point out main vulnerabilities of Russian's FEC that depend on foreign help (in terms of technology or money). Another useful research should be focused on indepth analysis of compliance of all the involved parties with main advises proposed by the Strategy. So far, Energy Strategy has served as an advisory documents, but it would be useful for the country to adopt it more seriously because following short and long-term business interests, which are in most of the time are private, may lead FEC to an exhaustion that potentially can dim perspectives for Russian people and the country itself. 


\section{References}

Bushuev, V. (2014, February 17). Project energy strategy of Russia till 2035 [power point presentation]. Retrieved from http://www. energystrategy.ru/ab_ins/source/Bushuev_ES-2035-17.02.14.pdf

Central Intelligence Agency. (2014, June 20). The world Factbook. Central Asia: Russia [online database]. Retrieved from https://www. cia.gov/library/publications/the-world-factbook/geos/rs.html

Government of Russian Federation. (2008, November 17). Concept of a long-term socio-economic development of Russian Federation till 2020. Approved by the Decree N1662-r of Government of the Russian Federation. Retrieved from http://www. consultant.ru/document/cons_doc_LAW_90601/?frame=1\#p28

"History of new Russia: 2002." n.d. Retrieved January 24, 2015, from http://www.ru-90.ru/chronicle/2002

"History of new Russia: 2003." n.d. Retrieved January 24, 2015, from http://www.ru-90.ru/chronicle/2003

"History of new Russia: 2008." n.d. Retrieved February 3, 2015, from http://www.ru-90.ru/chronicle/2008

"History of new Russia: 2009." n.d. Retrieved February 3, 2015, from http://www.ru-90.ru/chronicle/2009

Hodges, P. (2014, May 14). Europe faces Russian gas and oil supply risk over Ukraine. ICIS.com. Retrieved from http://www.icis.com/ blogs/chemicals-and-the-economy/2014/05/europe-faces-russian-gas-and-oil-supplies-risk-over-ukraine/

Kutiyn, N. (n.d.). Ecological problems and security of fuel and energy complex of Russia. City Expertise centre. Retrieved from http://www.gce.ru/news_day/nikolaj_kutin_ekologicheskie_problemy_i_bezopasnost_toplivnoenergeticheskogo_kompleksa_rossii/

Medvedev announced the necessity to decrease share of import in FEC to $10 \%$ by 2035. (2015, March 18). Interfax. Retrieved from http://www.interfax.ru/business/430709

Medvedev will conduct a conference to discuss energy strategy of Russia till 2035. (2015, March 18). Ria Novosti. Retrieved from http://ria.ru/economy/20150318/1053097649.html

Ministry of Energy of Russian Federation. (2003, August 28). Energy Strategy of Russia till 2020. Approved by the Decree N1234-r of Government of the Russian Federation.

Ministry of Energy of Russian Federation. (2009, November 13). Energy Strategy of Russia till 2030. Approved by the Decree N1715-r of Government of the Russian Federation.

Ministry of Energy of Russian Federation. (2013, March). Prognosis for the long-term socio-economic development of Russian Federation till 2030.

Ministry of Energy of Russian Federation. (2013, March). Roadmap of energy cooperation between Russia and EU till 2050.

Ministry of Energy of Russian Federation. (2014). Project Energy Strategy of Russia till 2035. Retrieved from http://minenergo. gov.ru/upload/iblock/621/621d81f0fb5a11919f912bfafb3248d6.pdf

Novak: energy strategy project will require $\$ 2.5$ trillion of investments. (2015, March 18). Ria Novosti. Retrieved from http://ria.ru/economy/20150318/1053212554.html

Pluzhnik, M.V., Saprikina, M.A. (2013). Energy security and energy security provision challenges in modern Russian economy. Russian entrepreneurship, N16 (238), pp. 41-50

"Projects - Energy Strategy of Russia - 2020." n.d. Institute of Energy Strategy. Retrieved February 20, 2015, from http://www.energy strategy.ru/projects/es-2020.htm

"Projects - Energy Strategy of Russia - 2030." n.d. Institute of Energy Strategy. Retrieved February 22, 2015, from http://www.energy strategy.ru/projects/es-2030.htm

"Projects - Energy Strategy of Russia - 2035." n.d. Institute of Energy Strategy. Retrieved February 25, 2015, from http://www.energystrategy.ru/ab_ins/source/15.01.14.htm

Project energy strategy of Russia till 2035 will be discussed February 17, 2014. (2014, February 13). Neftegas.ru. Retrieved from http://neftegaz.ru/news/view/119892/

U.S. Energy Information Administration. (2014, March 12). Overview analysis for Russia [Statistics]. Retrieved from http://www.eia. gov/countries/cab.cfm?fips=RS

Zilberstein, O. (2014, May 5). Assesment of the energy industry role in structure of the Russian economy and formation of national power safety indicators. Economy and modern management: theory and practice: compendium of reports of $32^{\text {nd }}$ international scientific-practical conference. Retrieved from http://sibac.info/14671 